\title{
Physiological and Oxidative Effects of Native \\ Piperaceae From Brazilian Amazon on Growth of Weed
}

\author{
Claudiene Rafalski \\ Graduate Program in Agronomy, Federal University of Paraíba - UFPB, Rodovia PB 079 - \\ Km 12, Areia, Paraíba, Brazil, 58.397-000, ninarafalski@ hotmail.com ORCID:
}

\begin{abstract}
Alessandra de Rezende Ramos
Institute of Health and Biological Studies, Federal University of the South and Southeast of Pará - UNIFESSPA, Avenida dos Ipês s/n, Cidade Jardim, Marabá, Pará, Brazil, 68.500-000, rezende@unifesspa.edu.br ORCID: https://orcid.org/0000-0001-9566-4333
\end{abstract}

Elizabeth Amélia Alves Duarte (corresponding author)

Graduate Program in Biotechnology- PPGBiotec, Maria Milza College - FAMAM, BR-101, Governador Mangabeira - Bahia, Brazil, 44350-000, Mobile: +55 (73) 99919-2229, elizabethaad@gmail.com ORCID: https://orcid.org/0000-0002-8667-502X

\section{Ilmarina Campos de Menezes}

Embrapa Eastern Amazon, Travessa Doutor Enéas Pinheiro, s/n, Marco, Belém, Pará, Brazil, 66095-903, ilmarina.menezes@embrapa.br

Thiago Alves Santos de Oliveira

Graduate Program in Biotechnology- PPGBiotec, Maria Milza College - FAMAM, BR-101, Governador Mangabeira - Bahia, Brazil, 44350-000, oliveira.tas@gmail.com ORCID: https://orcid.org/0000-0002-6582-7434

\section{Roseane Cavalcanti dos Santos}

Embrapa Cotton - National Cotton Research Center, R. Osvaldo Cruz, 1143, Centenário, Campina Grande, Paraíba, Brazil, 58428-095, roseane.santos@embrapa.br ORCID: https://orcid.org/0000-0002-9039-946X 
MlMacrothink

Received: Sep. 28, 2020

doi:10.5296/jas.v8i4.17755
Journal of Agricultural Studies

ISSN 2166-0379

2020, Vol. 8, No. 4

Accepted: Oct. 29, 2020

Published: Nov. 4, 2020

URL: https://doi.org/10.5296/jas.v8i4.17755

\begin{abstract}
The use of bioherbicides for the sustainable management of weeds is one of the main challenges of agriculture. With this approach, the application of complex (crude) extract has shown to be inore efficient and less expensive due to phytotoxic (together) presence, than single, isolated, or majority compounds. In this perspective, the aqueous extract of the five Piper spp. (Piper divaricatum, P. hispidum, P. marginatum, P. peltatum, and P. reticulatum) native from the Amazon region, Brazil were used to evaluate the physiological and oxidative effects on the emergence and growth of common weeds under controlled conditions and in greenhouse. The extract obtained in sufficient quantity and the expected inhibitory effect was used in biochemical assays again with lettuce (indicator plant) and weeds seedlings, focusing on antioxidative enzymes activity. We verify the allelopathic potential of the $P$. divaricatum and $P$. peltatum, which caused high toxicity to lettuce and weeds seedlings in vitro and in vivo assays. In both Piper extract at $1.5 \%$, the emergence inhibition of weed seedlings was up to $70 \%$. This concentration also influenced the growth of seedlings. As to responses of antioxidative enzymes, we found that lettuce seedlings were widely affected by the exposition of Piper extracts ( $P$. divaricatum and P. peltatum) at 5\%, with an input of $89 \%$, $300 \%$, and $290 \%$ on SOD, CAT, and APX activities, respectively. Thus, Piper divaricatum and $P$. peltatum are potent allelopathic species that could contribute to minimize the damage of crops caused by weed competitions.
\end{abstract}

Keywords: Allelopathy, Piper extracts, Antioxidative enzymes, weed control, natural herbicide

\title{
1. Introduction
}

Weeds are a severe problem to several crops due to their diversity, persistence in the field, competitiveness, and fast reproduction cycle. Several control methods are available, although synthetic herbicides are more effective and widely adopted by farmers (Jabran, 2017). Despite efficiency, the continuous use of synthetic herbicides poses a severe threat to human health and the environment due to the absorption of degraded products in the soil; some of them are persistent for an extended period (Albuquerque et al., 2010).

However, "the enemy lives next door". A number of herbicide-resistant weeds is growing, reaching 514 unique cases (species x site of action), which means 23 out of 26 action sites out of 167 herbicides known and authorized worldwide, according to updated data (august 2020) by the International Herbicide-Resistant Weed Database (Heap, 2020). Alternatively, bioherbicides could overcome such problems because synthetize natural toxins from plants that often inhibit the emergence of weeds (Carvalho et al., 2019; Leather, 1983). These allelochemicals may be released into the surrounding environment in sufficient amounts with enough persistence to affect the development of competing plants (Bais et al., 2003; Caser et 
al., 2020; Demasi et al., 2019).

The allelochemicals have several molecular targets and produce toxic effects in many weeds. The results depend on the concentration and are modulated by temperature, $\mathrm{pH}$, among others (Albuquerque et al., 2010; Reigosa et al., 2013; Seiber et al., 2018). At the physiological level, allelochemicals affect cell division, membrane permeability, photosynthesis, and plant growth. The inhibition of emergence occurs due to the triggering of a chain of ROS (reactive oxygen species) that cause $\mathrm{Ca}^{2+}$ signaling cascades leading to the death of the root system (Bais et al., 2003; Das \& Roychoudhury, 2014; Galindo et al., 1999; Reigosa et al., 2013).

ROS include free radicals such as superoxide anion $\left(\mathrm{O}_{2}{ }^{\cdot-}\right)$, hydroxyl radical $(\bullet \mathrm{OH})$, as well as non-radical molecules like hydrogen peroxide $\left(\mathrm{H}_{2} \mathrm{O}_{2}\right)$, singlet oxygen $\left({ }^{1} \mathrm{O}_{2}\right)$, among others. The input of ROS production during environmental stresses can threaten cells by causing peroxidation of lipids, oxidation of proteins, damage to nucleic acids, enzyme inhibition, and even activation of the PCD pathway (Sharma et al., 2012). The production of soluble antioxidant enzymes is one of the primary protective responses of plants against ROS. The SOD (superoxide dismutase), the most effective intracellular enzyme antioxidant, provides the first line of defense against the toxic effects of ROS (Bais et al., 2003; Czarnocka \& Karpiński, 2018; Reigosa et al., 2013). Catalase (CAT) and Peroxidase (POX) scavenge toxic $\mathrm{H}_{2} \mathrm{O}_{2}$ and provide tolerance to plants against biotic and abiotic stresses (Ünyayar et al., 2005). Thus, the different metabolic pathways studied report that the ROS produced by allelochemicals act directly or as a signal in cell degradation processes, causing physiological damages and altering the initial development of seedlings (Almeida et al., 2008; Roychoudhury et al., 2012).

The input of antioxidative enzymes due to the oxidative process is varied depending on the intensity, duration, and type of stress; however, CAT has a differential role in this response because it is critical for maintaining the redox balance during the oxidative stress (Czarnocka \& Karpiński, 2018). In conditions of severe stress, CAT has a high-speed turnover rate in oxidized tissues due to the availability of $\mathrm{H}_{2} \mathrm{O}_{2}$ produced in cells (Dubey, 2011). In tolerant plants, the neutralization capacity of $\mathrm{H}_{2} \mathrm{O}_{2}$ is fast, about $107 \mathrm{~min}^{-1}$, whose action occurs even before its diffusion through the cell. APX and CAT belong to two different classes of $\mathrm{H}_{2} \mathrm{O}_{2}$ scavenging enzymes where APX (ascorbate peroxidase) is responsible for the slight modulation, whereas CAT is responsible for removing the excess ROS during physiological stress (Akcay et al., 2010; Das \& Roychoudhury, 2014).

In this sense, the action of antioxidant molecules released by plants, as well as already known secondary metabolites - saponins, tannins, flavonoids, terpenoids, and lactones -, are critical components in prospecting and allelopathic tests for further development of bioherbicides (Bachheti et al., 2020; Duke \& Dayan, 2013; Rice, 1985; Singh et al., 2009). Another attractive and advantageous characteristic of allelochemicals is that they are not halogenated like synthetic herbicides, which making them safer for non-target organisms (Chon et al., 2003). Additionally, allelopathy has been reported as a viable alternative due to the diversity of allelochemicals, practicality, and safety to human beings and the environment in weed management (Sodaeizadeh \& Hosseini, 2012). Despite the several works of literatures on allelopathic potential, many of which are already synthesized and used from Japan, USA, and 
Germany, the studies related to oxidative stress caused by allelochemicals are still insipient (Ayeni \& Kayode, 2014; Gerwick \& Sparks, 2014; Tigre et al., 2012). Several chemical components that some Piperaceae species bring together, making them allelopathic potentials.

However, species of Piper natives from the Amazon region, Brazil, that do not have added value like Piper nigrum (black pepper) are attractive, presenting low cost, fast growth, and holds several known metabolites, such as alkaloids, lignans, flavonoids, chromenes, pyrones, piperolides, terpenes, and phenylpropanoids, all promising for weed control (Da Silva et al., 2017; Dyer et al., 2004).

The properties of Piperaceae are widely reported in the literature, mainly antifungal, allelopathic, volatile compounds, antioxidant and cytotoxic activities (Arambewela et al., 2005; Baldin et al., 2015; Corpes et al., 2019; Da Silva et al., 2010; Da Silva et al., 2011; Da Silva et al., 2014a-b; Da Silva et al., 2017; Hermoso et al., 2003; Pukclai \& Kato-Noguchi, 2011; Reddy et al., 2004). Here, we evaluate the physiological and oxidative effects of Piper extracts in weeds based on in vivo and in vitro tests. Piper spp. accessions were kindly provided by the curator of the Piperaceae germplasm bank, from Embrapa Amazônia Oriental (Belém, PA, Brazil).

\section{Method}

\subsection{Prospective Trial of Piper Extracts on Lettuce}

Five accessions of Piper spp. were kindly provided by the curator of Piperaceae germplasm bank, maintained at Embrapa Amazonia Oriental (Belem, PA, Brazil), 01²8'46” S 48 20'4.6” W, 42 m. Exsiccates of each germplasm are deposited in Goeldi Museum (MG) and Instituto Agronomico do Norte (IAN), both in Belem, PA, Brazil, with respective codes: Piper divaricatum G. F. W. Mey. (MG 162212), P. hispidum Hatus (MG 150675), P. marginatum Jacq. (MG 184921), P. peltatum L. (MG 150681) and P. reticulatum L. (IAN 197423). The seeds of lettuce (Lactuca sativa L.) and weeds: burgrass (Cenchrus echinatus L.), hairy beggar'sticks (Bidens pilosa L.) and sourgrass (Digitaria insularis L.) Mez ex Ekman were purchased commercially.

Crude extracts (10\% v:v) of dried and grounded young leaves $\left(50{ }^{\circ} \mathrm{C}\right.$ for $\left.72 \mathrm{~h}\right)$ were performed in $\mathrm{diH}_{2} \mathrm{O}$ at $10 \%$ and further mixed on an orbital shaker for $4 \mathrm{~h}$, at room temperature. Then, extracts were filtered in paper Whatman ${ }^{\circledR} \mathrm{N}^{\mathrm{o}} 2$ ), and two dilutions were prepared from the crude extract at $5 \%$ and $7.5 \%$ for further experimental assays. Fifty lettuce seeds, previously sterilized in hypochlorite solution (5\%), were placed on Petri dishes (90 $\mathrm{mm} \varnothing$ ), lined with two filter paper Whatman ${ }^{\circledR} \mathrm{N}^{\circ} 2$ moistened with $1.5 \mathrm{~mL}$ of each Piper extracts, at $5 \%$ and $7.5 \%$. The Petri dishes were incubated in BOD at $26{ }^{\circ} \mathrm{C} \pm 1$ and photoperiod of 12:12 for 7 days. The moisture was maintained with the application of $500 \mu \mathrm{L}$ of $\mathrm{diH}_{2} \mathrm{O}$ to each $48 \mathrm{~h}$. The experiment followed a completely randomized design, with a factorial $(5 \times 2+1)$ and 5 replications. Seed emergence, seedling height, and main root length were measured at the end of assay.

\subsection{Inhibition Bioassay of Piper Extracts on Weeds Growth}

This assay was performed with extracts of $P$. divaricatum and $P$. peltatum at $7.5 \%$ that 
inhibited the lettuce emergence $\geq 80 \%$ in the above assay. According to described above, the experiment was carried out using fifty seeds of burgrass, hairy beggar'sticks and sourgrass. The investigation followed a completely randomized design, with a factorial $(3 \times 2 \times 5+1)$, corresponding to three weeds and two Piper extracts, and five replications. The same parameters: seed germination, seedling height, and main root length were measured 10 days after sowing (DAS).

\subsection{Antioxidative Activity Assay in Weeds Grown on Piper Extract}

The antioxidative activity assays were carried out with SOD (EC 1.15.1.1), CAT (EC 1.11.1.6), and APX (EC 1.11.1.11) enzymes. Seeds of lettuce and weeds (burgrass, hairy beggar' sticks, and sourgrass) were imbibed on Piper extracts ( $P$. divaricatum and $P$. peltatum) at 5\% during 10 days. The samples were homogenized from three biological replicates (10 seeds) and five experimental ones (Petri dishes), totalizing 50 seedlings per treatment.

A homogenized crude extract $(25 \%)$ was prepared by grinding frozen tissues in $100 \mathrm{mM}$ potassium phosphate buffer ( $\mathrm{pH} 7.0$ ) containing 0.1 mM EDTA.

SOD activity was assayed according to Elstner \& Heupel (1976) and absorbance was measured at $560 \mathrm{~nm}$, considering the inhibition of NBT reduction by dismutation of superoxide. CAT and APX activities were estimated according to Beers \& Sizer (1952) and Nakano \& Asada (1981). The unit of CAT activity was defined as a decrease in absorbance at $240 \mathrm{~nm}$ of 0.01 per minute, and a unit of APX activity was defined as the enzyme that oxidizes $1 \mu \mathrm{mol}$ of ascorbate per minute. SOD, CAT, and APX enzymes activity were expressed as katals $\left(\mathrm{mg}^{-1}\right)$ produced per protein mass.

\subsection{Validation of Piper Extract Toxicity on Weeds Grown in Greenhouse}

The toxicity of Piper extracts ( $P$. divaricatum and $P$. peltatum) on weeds under a greenhouse was performed based on the optimum concentration (7.5\%), in vitro, obtained in this study, in addition to the 1.5 and $3.5 \%$ that showed oxidative effects and the presence of phenolic compounds with Piper divaricatum.

One hundred seeds of lettuce and weed seeds (burgrass, hairy beggar' sticks, and sourgrass) were sown in trays $(27 \times 19 \times 3 \mathrm{~cm})$ filled with a substrate (Plantmax $®)$ and vermiculite (1: 1) at $30 \pm 2{ }^{\circ} \mathrm{C}, 58 \pm 3 \% \mathrm{RH}$ and 12:12 photoperiod. The experiment followed a completely randomized design, with four species, two Piper extracts ( $P$. divaricatum and P. peltatum) and four concentrations $(1.5 \%, 3.5 \%, 5.5 \%$, and $7.5 \%)$, with 5 replications. Each tray was daily watered with $500 \mathrm{~mL}$ of Piper extract or $\mathrm{diH}_{2} \mathrm{O}$ until saturation of the substrate, previously determined. Seed emergence, seedling height, and main root length were measured 10 days after sowing (DAS).

\subsection{Statistical Analysis}

Data were submitted to analysis of variance (ANOVA), and means were compared by the Tukey test $(p \leq 0.05)$ using the statistical software R v.3.6.3 (R Core Team, 2020, RStudio v.1.2.5042 (RStudio Team, 2020), the ggplot2 package (v3.3.2; Wickham, 2016). 


\section{Results and Discussion}

Prospective trial of Piper extracts on lettuce

Lettuce seedlings were grown on different concentrations of Piper extracts for 7 days. Lettuce was included in the assay because is reported as a model species or indicator plant due to broad sensitivity to plant allelochemicals (Lustosa et al., 2007; Omid et al., 2019). High inhibition rates were found to growth traits of seedlings grown in presence of Piper extracts at 5 and $7.5 \%$ (table 1). The emergence rates of seedlings were reduced up to $20 \%$ with Piper extracts at 5\%, but broad phytotoxic effects to lettuce plants were found with $P$. divaricatum and $P$. peltatum extracts at $7.5 \%$ that inhibited the emergence in 77.5 and $93 \%$, respectively. The roots were sensitive to all Piper extracts, influencing seedling height, especially in treatments with $P$. peltatum extract at $7.5 \%$.

Table 1. Seed emergence and seedling growth of lettuce grown on Piper extracts

\begin{tabular}{|c|c|c|c|c|c|c|}
\hline \multirow{3}{*}{$\begin{array}{l}\text { Aqueous } \\
\text { extract }\end{array}$} & \multicolumn{2}{|c|}{ Seed germination $(\%)$} & \multicolumn{2}{|c|}{ Main root length $(\mathrm{mm})$} & \multicolumn{2}{|c|}{ Seedling heigth $(\mathrm{mm})$} \\
\hline & \multicolumn{6}{|c|}{ Piper extracts concentration (\%) } \\
\hline & 5.0 & 7.5 & 5.0 & 7.5 & 5.0 & 7.5 \\
\hline P. divaricatum & $41.0 \mathrm{cA}$ & $22.5 \mathrm{cB}$ & $5.2 \mathrm{cA}$ & $0.2 \mathrm{cB}$ & $4.5 \mathrm{cA}$ & $3.2 \mathrm{cA}$ \\
\hline P. peltatum & $18.5 \mathrm{dA}$ & $7.0 \mathrm{~dB}$ & $5.7 \mathrm{cA}$ & $0.0 \mathrm{cB}$ & $5.2 \mathrm{cA}$ & $1.0 \mathrm{~dB}$ \\
\hline P. marginatum & $59.0 \mathrm{bcA}$ & $26.0 \mathrm{cB}$ & $9.5 \mathrm{bA}$ & $1.7 \mathrm{bcB}$ & $7.7 \mathrm{bcA}$ & $3.5 \mathrm{cB}$ \\
\hline P. reticulatum & $80.0 \mathrm{bA}$ & $34.0 \mathrm{bB}$ & $8.2 \mathrm{bcA}$ & $1.0 \mathrm{bcB}$ & $9.2 \mathrm{bA}$ & $3.5 \mathrm{cB}$ \\
\hline P. hispidum & $76.5 \mathrm{bA}$ & $36.0 \mathrm{bB}$ & $10.0 \mathrm{bA}$ & $3.7 \mathrm{bB}$ & $10.0 \mathrm{bA}$ & $7.0 \mathrm{bB}$ \\
\hline Control $\left(\mathrm{diH}_{2} \mathrm{O}\right)$ & $100.0 \mathrm{aA}$ & $100.0 \mathrm{aA}$ & $61.5 \mathrm{aA}$ & $61.5 \mathrm{aA}$ & $16.7 \mathrm{aA}$ & $16.7 \mathrm{aA}$ \\
\hline${ }^{1} \mathrm{C} . \mathrm{V}(\%)$ & 13.33 & & 6.23 & & 7.46 & \\
\hline
\end{tabular}

${ }^{1}$ Coefficient of variation. Means followed by the same letter do not differ by Tukey's test ( $p \leq$ 0.05). Capital letter compares between concentrations (line); lowercase letters compare between treatments (columns).

The abundance of phytochemicals in Piper species have been well reported in the literature. Several of the present broad cytotoxic and antimicrobial activities due to benzoic acid derivatives, chromenes, and flavonoids, among others organic compounds (Da Silva et al., 2014a-b; Moreira et al., 1998). Many allelochemicals in plants dramatically affect seed germination (Bachheti et al., 2020). In this phase, a rapid increase in glycolytic activity is 


\section{Ml Macrothink}

Journal of Agricultural Studies

ISSN 2166-0379

2020, Vol. 8, No. 4

necessary to mobilize stored carbohydrates to provide ATP to seeds and further energy for the biosynthesis of roots and leaves (Podestá \& Plaxton, 1994). An impediment in the synthesis of metabolites necessary to these functions leads to cell imbalance with consequences in plants' antioxidative system. Here, several deformed plants were observed with deep oxidation symptoms at the tip of roots during the lettuce growth, preventing seedlings' growth (figure 1). These symptoms were also reported by others authors using highly-allelopathic species. Some allelochemicals can induce abnormality in seedlings, with necrosis of radicle that is a frequent symptom. With Piper, Lustosa et al. (2007) tested the bioactivity of aqueous extracts (1\% to 5\%) of P. aduncum L. and P. tectoniifolium on lettuce growth and found inhibition rate of $66 \%$ and $74 \%$ respectively, in the emergence of seedlings. These results confirm that several Piper spp. are highly toxic against lettuce.
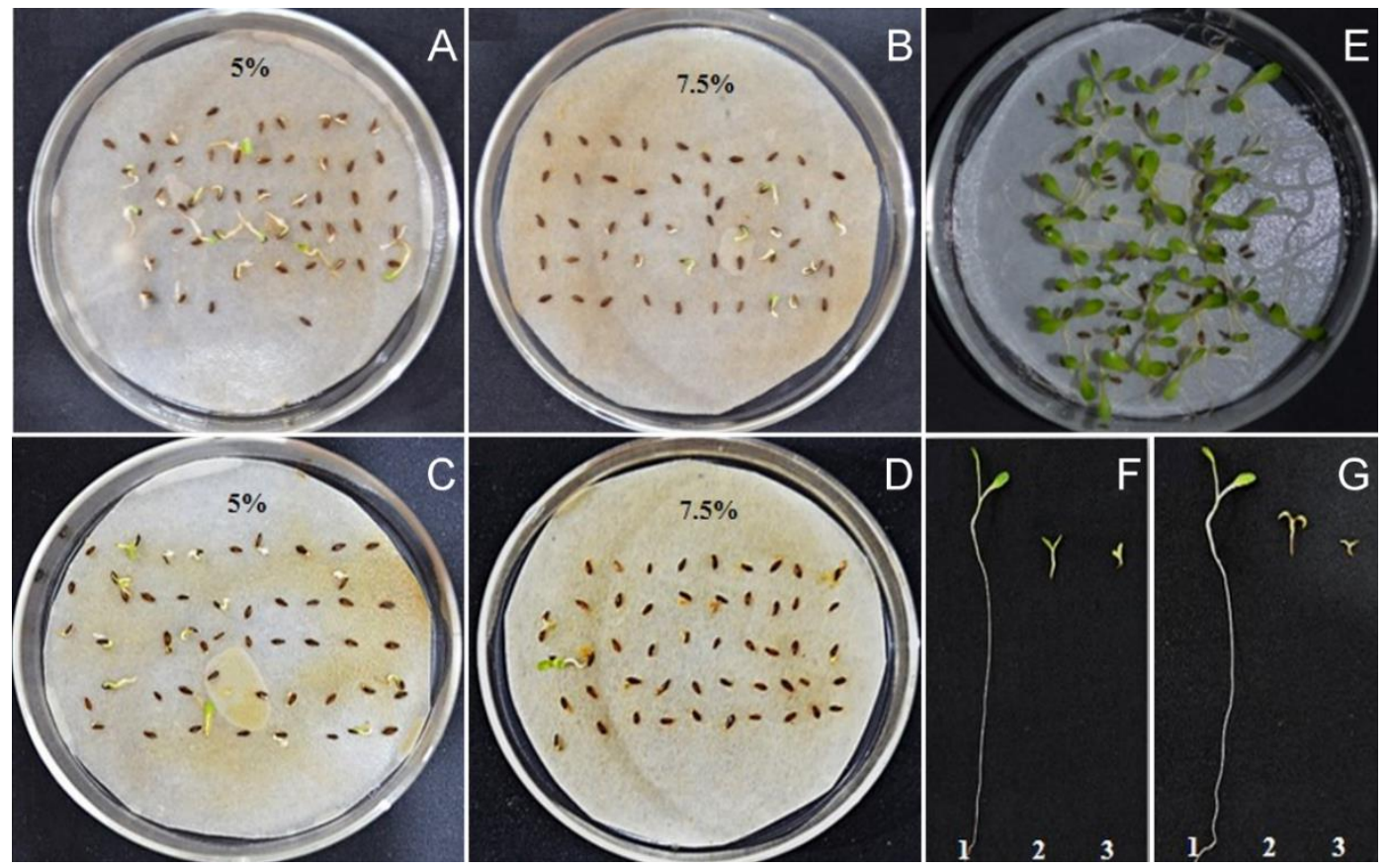

Figure 1. Toxicity symptoms in lettuce seedlings grown in extracts of Piper A-B and F: $P$. divaricatum; C-D and G: P. peltatum. E: Control $\left(\mathrm{diH}_{2} \mathrm{O}\right)$

Activity of Piper extracts on weed growth

Based on the results above presented, the aqueous extracts of $P$. divaricatum and $P$. peltatum at $7.5 \%$ were chosen for weed trials carried out in BOD. High growth inhibition was found in the three weeds with a wide harmful effect of $P$. peltatum extract that inhibited practically the whole physiological capacity of the seedlings (table 2 and figure 2). The tip of roots showed oxidation symptoms, as seen in lettuce seedlings, confirming the high toxicity of allelochemicals present on extracts. Although this result is from an in vitro assay, we confirm the high toxicity of $P$. peltatum aqueous extract, as seen on the emergence and growth of lettuce plants (table 1). In literature, others Piper species have been reported with high toxicity against weeds and commercial crops. Borella et al. (2012) found physiological damages in radish (Raphanus sativus) seedlings grown in aqueous extracts of $P$. mikanianum at $4 \%$, with drastic effects on roots and leaves. Hong et al. (2002) evaluated the response of 
Kava (P. methysticum) extract at low concentrations in barnyard grass (Echinochloa crus-galli (L). P. Beauv) and duck-tongue (Monochoria vaginalis (Burm.f.) C.Presl) and found potent inhibition in growth of plants.

Table 2. Seed emergence and seedling growth of weeds grown on Piper extracts at $7.5 \%$

\begin{tabular}{|c|c|c|c|c|c|c|c|c|c|}
\hline \multirow{2}{*}{ Weeds } & \multicolumn{3}{|c|}{ Seed germination $(\%)$} & \multicolumn{3}{|c|}{$\begin{array}{c}\text { Main root length } \\
(\mathbf{m m})\end{array}$} & \multicolumn{3}{|c|}{ Seedling heigth $(\mathrm{mm})$} \\
\hline & $\mathbf{T 1}$ & $\mathbf{T} 2$ & $\mathbf{C}$ & T1 & $\mathbf{T} 2$ & $\mathbf{C}$ & T1 & $\mathbf{T} 2$ & $\mathbf{C}$ \\
\hline Burgrass & $\begin{array}{l}11.1 \\
b B\end{array}$ & $\begin{array}{l}2.0 \\
\mathrm{bC}\end{array}$ & $48.0 \mathrm{bA}$ & $\begin{array}{c}11.0 \\
\mathrm{aB}\end{array}$ & $\begin{array}{l}5.0 \\
\mathrm{aB}\end{array}$ & $\begin{array}{c}40.0 \\
\mathrm{bA}\end{array}$ & $\begin{array}{l}6.0 \\
\mathrm{aB}\end{array}$ & $\begin{array}{l}4.6 \\
\mathrm{aB}\end{array}$ & $55.0 \mathrm{aA}$ \\
\hline Beggar'sticks & $\begin{array}{c}18.0 \\
b B\end{array}$ & $\begin{array}{l}0.0 \\
\mathrm{bC}\end{array}$ & $64.8 \mathrm{bA}$ & $6.0 \mathrm{aB}$ & $\begin{array}{l}0.0 \\
\mathrm{bC}\end{array}$ & $\begin{array}{c}39.0 \\
\mathrm{bA}\end{array}$ & $\begin{array}{l}8.0 \\
\mathrm{aB}\end{array}$ & $\begin{array}{l}0.0 \\
\mathrm{bC}\end{array}$ & $18.0 \mathrm{bA}$ \\
\hline Sourgrass & $4.4 \mathrm{cB}$ & $\begin{array}{l}0.0 \\
b B\end{array}$ & $50.8 \mathrm{bA}$ & $1.8 \mathrm{bB}$ & $\begin{array}{l}0.0 \\
\mathrm{bB}\end{array}$ & $\begin{array}{c}33.0 \\
\mathrm{bA}\end{array}$ & $\begin{array}{l}2.6 \\
b B\end{array}$ & $\begin{array}{l}0.0 \\
b B\end{array}$ & $11.0 \mathrm{bA}$ \\
\hline C.V\% & & 15.67 & & & 11.16 & & & 7.5 & \\
\hline
\end{tabular}

T1: P. divaricatum, T2: $P$. peltatum extracts. Means followed by the same letter do not differ by Tukey's test $(p \leq 0.05)$. Capital letter compares between concentrations (line); lowercase letters compare between treatments (columns). 


\section{Macrothink Institute ${ }^{T M}$}

A
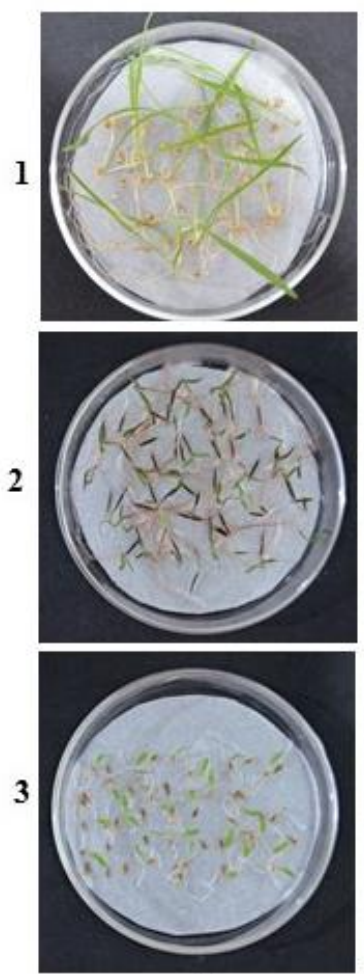

C
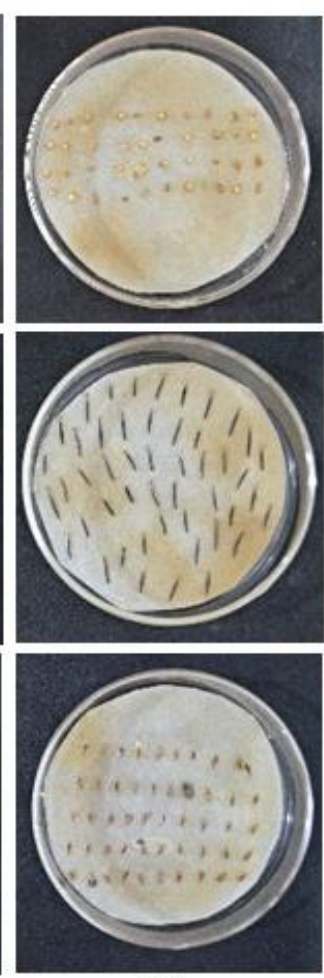

T1
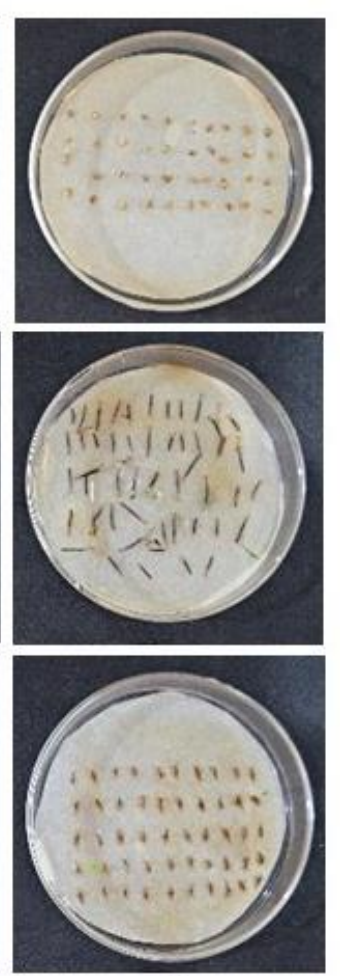

T2
Journal of Agricultural Studies

ISSN 2166-0379

2020, Vol. 8, No. 4

B
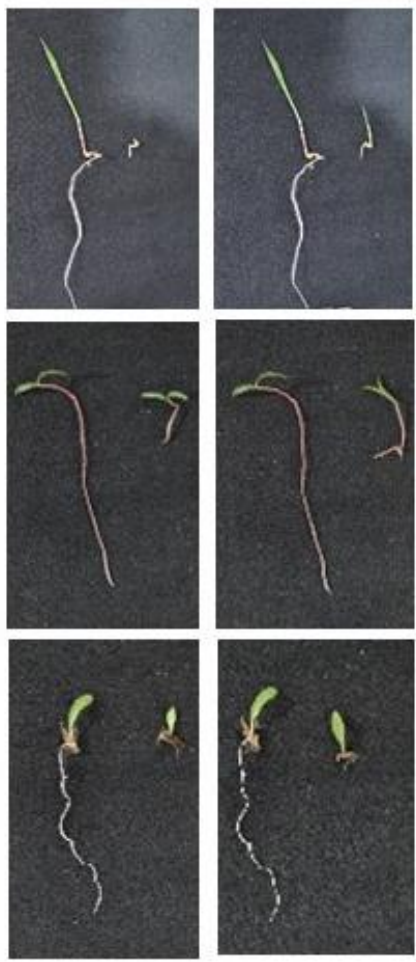

C Tl

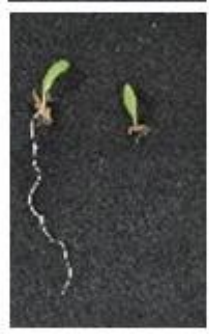

C $\quad$ T2

Figure 2. Toxicity symptoms in weed seedlings grown on extracts of Piper extracts at $7.5 \%$. A- Emergence of burgrass (1), hairy beggarticks (2) and sourgrass (3). T1- P. peltatum, T2- P. divaricatum; B- Growth of the seedlings. C- Control $\left(\mathrm{diH}_{2} \mathrm{O}\right)$

\section{Antioxidative activity of lettuce and weeds grown in Piper extracts}

Based on oxidation symptoms seen in root tips of lettuce and weed seedlings, the activity of antioxidative enzymes was estimated in all species grown on the presence of $P$. peltatum extract, considering the broad toxicity found in emergence and growth bioassays. The tissues were collected from seedlings grown only on extract at $5 \%$, due to the low emergence of weeds grown at $7.5 \%$ and insufficient amount of tissues for further assays.

The profiles of SOD, CAT, and APX are found in Figure 3. The input of activities found in all species grown in the presence of $P$. peltatum extract suggested that oxidative stress was an important factor responsible for damages to plant growth. Considering the amount of superoxide's necessary to start the dismutation process due to oxidative stress, we noticed that lettuce were more agile in the defense process, showing input of $175 \%, 400 \%$, and $300 \%$ in SOD, CAT, and APX activities, respectively. Sourgrass was slower; however, all of the others weeds mobilized the oxidative machinery in order to minimize the cell damage. The amount of toxic components present in the aqueous extract, although at low concentration, was sufficient to promote oxidative damage in seedlings, as seen in figs 1 and 2. 

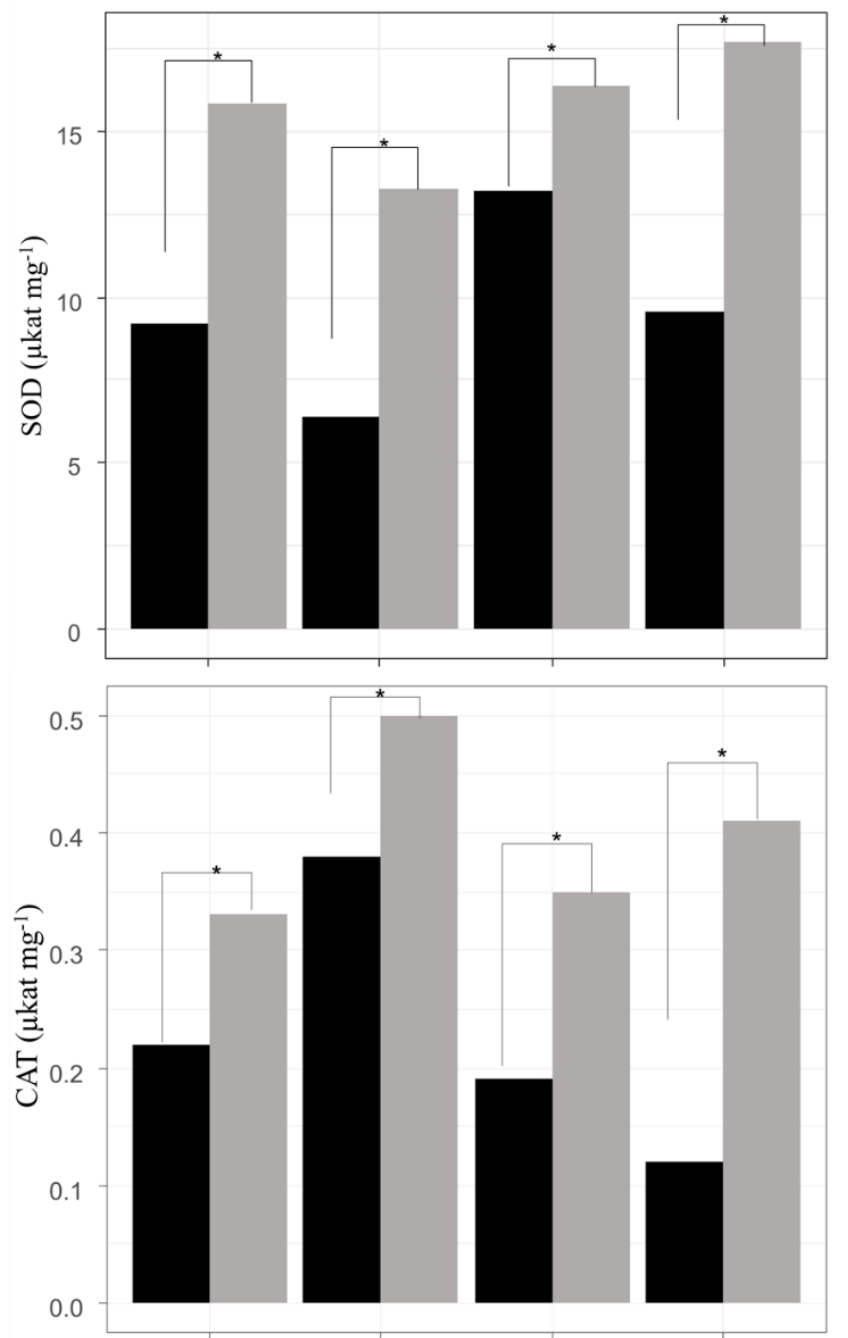

Concentration
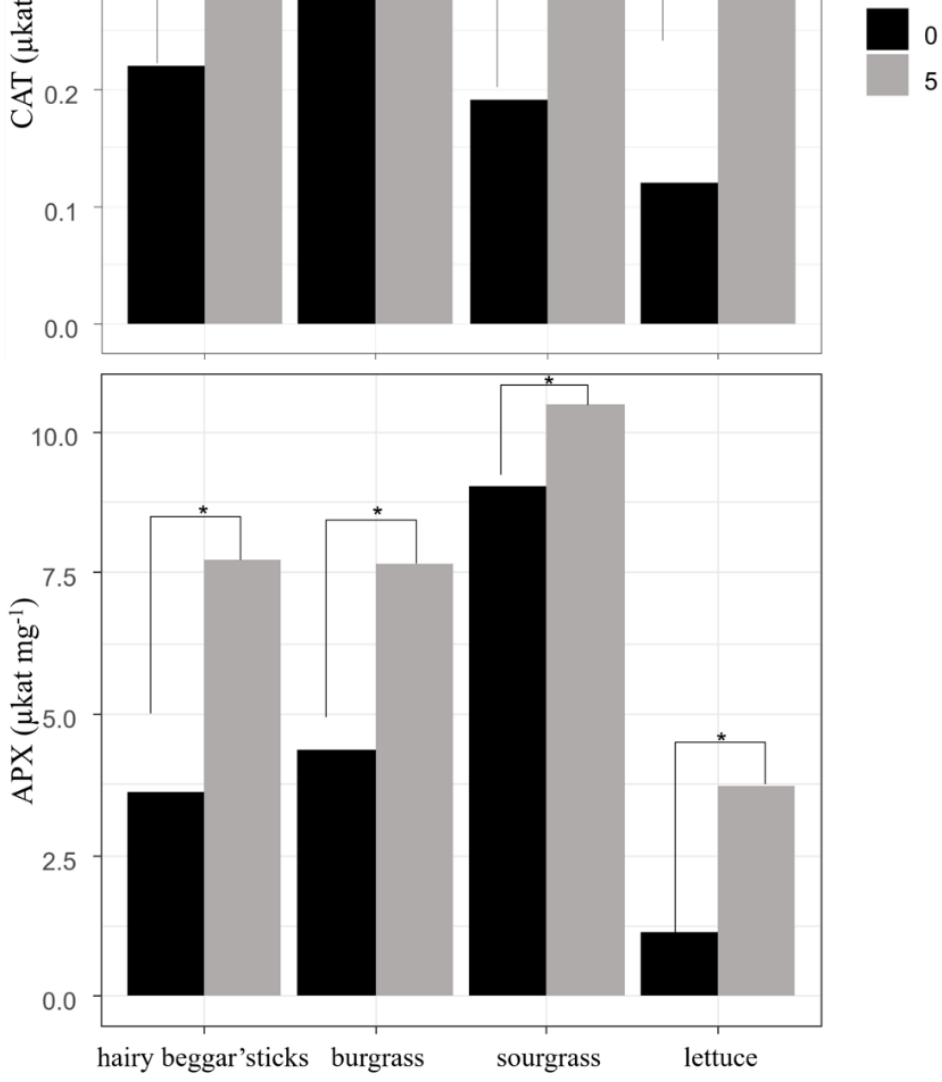

Figure 3. Antioxidative activities of SOD, CAT, and APX enzymes in tissues of weed (hairy beggar'sticks, burgrass, sourgrass) and lettuce seedlings grown on aqueous extracts of Piper peltatum at $5 \%$. Control: replaced the extract with $\mathrm{diH}_{2} \mathrm{O}$. $*$ Differ by $\mathrm{F}$ test. 
Oxidative damage caused in plants due to abiotic stresses has been widely reported in the literature, but reports with allelochemicals have been limited to few species. In lettuce, Aumonde et al. (2012) submitted seedlings to Zantedeschia aethiopica-leaf extract from 6\% to $50 \%$ and found increased activities of antioxidative enzymes in all concentrations, whose cell damages induced to abnormal plants. High SOD activity was observed from $12 \%$ extract and above $25 \%$ for CAT and APX. In seedlings, emergence and growth were drastically affected by $25 \%$ and 50\%. In Zea mays, Singh et al. (2009) submitted seedlings to grown in aqueous leachate of Nicotiana plumbaginifolia (25\% to 100\%) and found impairment of various metabolic activities due to phytotoxic nature of Nicotiana, which reduced radicle and plumule growth of maize seedlings. The activities of SOD and CAT increased at higher concentrations because of the oxidative damages caused by leachate to the seedlings.

Here, our results exhibited that SOD, CAT, and APX activities tend to increase under the influence of alellochemicals stress, corroborating with several reports found in the literature.

\section{Validation of Piper toxicity on the growth of weeds in greenhouse}

This trial was carried out in the greenhouse, using aqueous extracts of $P$. divaricatum and $P$. peltatum on the watering of weeds at $1.5 \%, 3.5 \%, 5.5 \%$, and $7.5 \%$. Total inhibition of the emergence of weeds and lettuce was found on treatments watered with extracts down to $3.5 \%$ of both Piper spp. At 1.5\%, lettuce's inhibition rate reached $60 \%$, while in hairy beggar' sticks, sourgrass, and burgrass, we found 89\%, 76\%, and 90\%, respectively (table 3). The growth of roots was reduced to $53 \%, 59 \%$, and $47 \%$ in lettuce, hairy beggar' sticks and sourgrass seedlings.

Table 3. Emergence and growth of weeds and lettuce watered with Piper extracts at $1.5 \%$ in the greenhouse

\begin{tabular}{|c|c|c|c|c|c|c|c|c|c|}
\hline \multirow{2}{*}{ Treatments } & \multicolumn{3}{|c|}{ Seed germination $(\%)$} & \multicolumn{3}{|c|}{ Main root length (mm) } & \multicolumn{3}{|c|}{ Seedling heigth (mm) } \\
\hline & $\mathbf{T 1}$ & $\mathbf{T 2}$ & $\mathbf{C}$ & $\mathbf{T 1}$ & $\mathbf{T 2}$ & $\mathbf{C}$ & $\mathbf{T 1}$ & $\mathbf{T 2}$ & $\mathbf{C}$ \\
\hline \multirow{3}{*}{ Burgrass } & 13.0 & 17.0 & 77.0 & 41.0 & & 82.0 & 12.0 & 15.0 & \\
\hline & $b B$ & $\mathrm{bB}$ & $\mathrm{bA}$ & $\mathrm{aB}$ & $46.0 \mathrm{aB}$ & $\mathrm{aA}$ & $\mathrm{cB}$ & $\mathrm{cB}$ & $34.0 \mathrm{cA}$ \\
\hline & & & 44.0 & 37.0 & & 84.0 & 30.0 & 29.0 & \\
\hline \multirow[t]{2}{*}{ Beggar'sticks } & $5.0 \mathrm{cB}$ & $6.0 \mathrm{cB}$ & $\mathrm{cA}$ & $\mathrm{aB}$ & $32.0 \mathrm{bB}$ & $\mathrm{aA}$ & $\mathrm{aB}$ & $\mathrm{aB}$ & $60.0 \mathrm{aA}$ \\
\hline & & & 18.0 & 21.0 & & 62.0 & 28.0 & 22.0 & \\
\hline \multirow[t]{2}{*}{ Sourgrass } & $3.0 \mathrm{cB}$ & $2.6 \mathrm{cB}$ & $\mathrm{dA}$ & $\mathrm{bB}$ & $22.0 \mathrm{cB}$ & $\mathrm{cA}$ & $\mathrm{aB}$ & $\mathrm{bC}$ & $47.0 \mathrm{bA}$ \\
\hline & 36.0 & 40.0 & 100.0 & 3.06 & & 72.0 & 19.0 & 21.0 & $310 \mathrm{~A}$ \\
\hline Lettuce & $\mathrm{aB}$ & $\mathrm{aB}$ & $\mathrm{aA}$ & $\mathrm{aB}$ & $37.0 \mathrm{bB}$ & $\mathrm{bA}$ & $\mathrm{bB}$ & $\mathrm{bB}$ & $31.0 \mathrm{CA}$ \\
\hline C.V\% & & 12.12 & & & 17.16 & & & 11.58 & \\
\hline
\end{tabular}




\section{Macrothink}

Journal of Agricultural Studies

ISSN 2166-0379

2020, Vol. 8, No. 4

T1: P. divaricatum; T2: P. peltatum; C: control $\left(\mathrm{diH}_{2} \mathrm{O}\right)$. Means followed by the same letter do not differ by Tukey's test $(p \leq 0.05)$. Capital letter compares between concentrations (line); lowercase letters compare between treatments (columns).

The most drastic effect was found to burgrass because the growth of roots was deeply affected to the few plants that were able to emerge, which reduction was about $68 \%$. Although this weed is widespread in nature, the germination rate of seeds in the natural conditions is often low due to environmental effects and meanly the outer capsule's rigidity that protects the seeds, whose emergence depends on the dehiscence (Sharif-Zadeh \& Murdoch, 2000). Klein \& Felippe (1991) investigated some aspects of several weeds' emergence, focusing on the seeds' photoblacial behavior. According to the authors, seeds of burger behave differently in relation to light, revealing a lower germination rate than the other invasive species studied.

As to the height of seedlings grown on Piper spp. extracts, lettuce plants showed a reduction of $33 \%$, whereas, in hairy beggar' sticks and burgrass, we found $50 \%$ and $67 \%$ to sourgrass. Figure 4 displays a view of lettuce and weeds seedlings grown in trays watered with Piper spp. extracts. Burgrass seedlings were not recorded due to poor representation in lanes in all repetitions. 


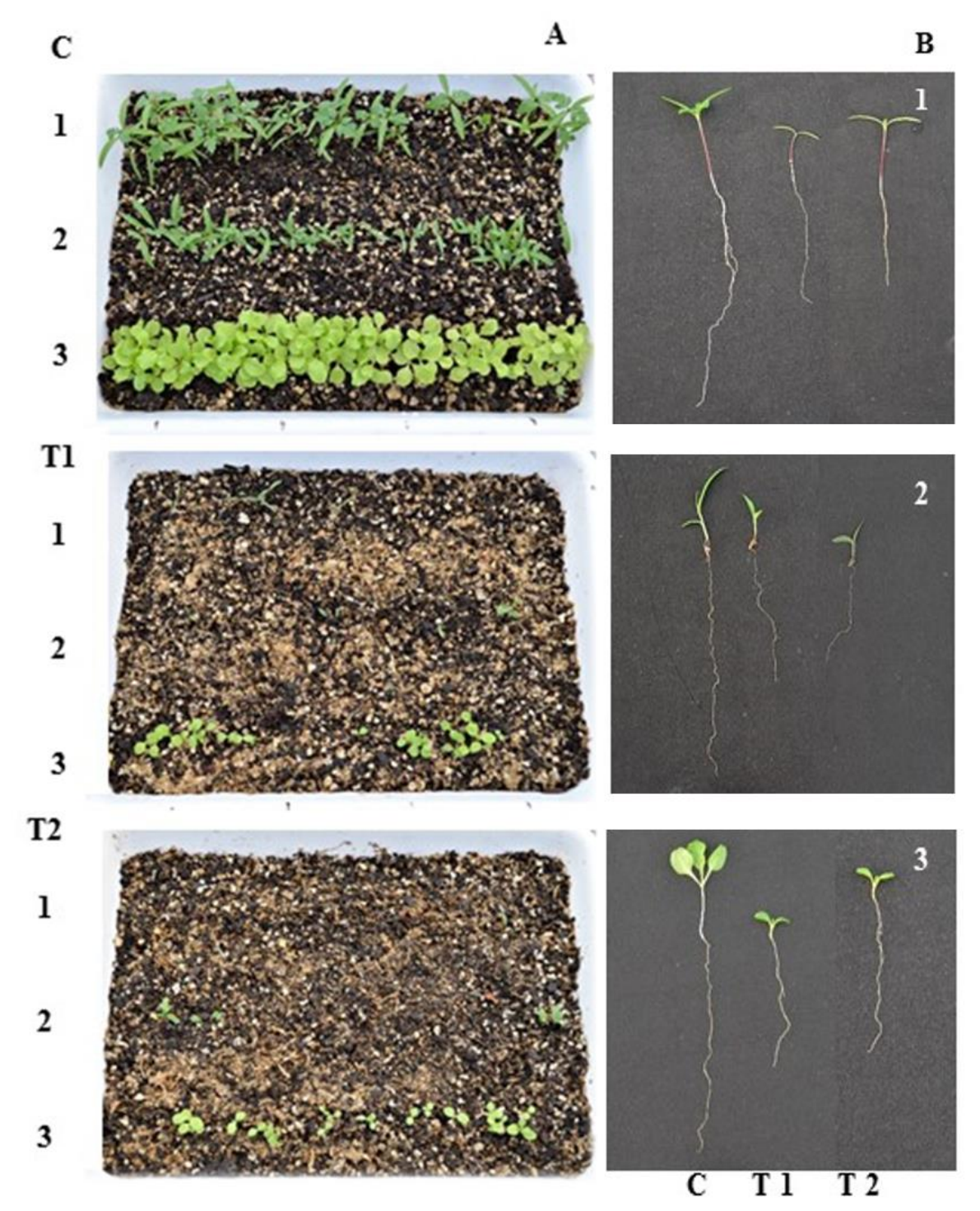

Figure 4. View of lettuce and weeds seedlings watered with $P$. divaricatum (T1) and $P$. peltatum (T2) piper extract at $1.5 \%$ in greenhouse. 1: lettuce, 2: beggarticks, 3: sourgrass, C: control $\left(\mathrm{diH}_{2} \mathrm{O}\right)$. A: Growth of the plants in trays, B: Root growth of seedlings

The results presented here provide evidence of the bioherbicidal potential of Piper extracts' on three important crop weeds. Following the worldwide trend to minimize the use of synthetic pesticides in agricultural management, the adoption of natural pesticides offers an opportunity to adopt biological inputs in agroecological systems.

Piper spp. have been reported as potent genetic resources to use in plant defenses against pathogens and weeds. According to Dyer et al. (2004), the genus Piper has about 667 different metabolites, which are distributed in the following classes: 190 alkaloids/amides, 49 lignans, 70 neolignans, 97 terpenes, 39 propenylphenols, 15 steroids, 18 kavapirones, 17 chalcones/dihydrochalcones, 16 flavones, 6 flavanones, 4 piperolides, and others. Among these, terpenes plays an important role in plant defense. Terpenes (mono-, sesqui-, di- and triterpenes) are usually highly hydrophobic substances and are stored in resin ducts, oil cells, or 
glandular trichomes, showing activities against a wide range of organisms, from bacteria and fungi to insects and vertebrates. As to Wink \& Schimmer (2010), terpenes can increase the membranes' fluidity, leading to uncontrolled efflux of ions and metabolites, modulation of membrane proteins and receptors, or even cell leakage, resulting in cell death. The sesquiterpenes, potent allelochemistry, occur in nature as hydrocarbons in oxygenated forms such as alcohols, ketones, aldehydes, acids, or lactones ( $\mathrm{Li}$ et al., 2010). Other allelopathic compounds are tannins, cyanogenic glycosides, alkaloids, flavonoids, and phenolic acids (King \& Ambika 2002; Rizvi \& Rizvi, 1992; Vásquez \& Roxana, 2015). According to some authors, $P$. peltatum and $P$. divaricatum contain sesquiterpenes as the main component of essential oil, which may be present in roots, leaves, and inflorescences (Da Silva et al., 2014a; Pinto et al., 2010).

\section{Conclusion}

Although we have worked with the crude extract, the aggregation of these molecules certainly enhanced the toxic effect on the emergence and growth of tested species. The inhibition results seen in the greenhouse, using Piper extracts at low concentration, are very encouraging and open perspectives to deepen the studies with these species, including their organic fractions, in order to identify the key metabolites responsible for the allelopathic effect in these species.

\section{Acknowledgments}

This study was financed in part by the Coordination for the Improvement of Higher Education Personnel -Brazil (CAPES), Finance Code 001. The authors would like to thank the Graduate Program in Agronomyc of the Federal University of Paraiba (UFPB) as well as the Museu Paraense Emílio Goeldi (MPEG), for the deposit of the exsiccatae and Embrapa Amazônia Oriental for the biological material provided.

\section{References}

Akcay, U. C., Ercan, O., Kavas, M., Yildiz, L., Yilmaz, C., Oktem, H. A., \& Yucel, M. (2010). Drought-induced oxidative damage and antioxidant responses in peanut (Arachis hypogaea L.) seedlings. Plant Growth Regulation, 61, 21-28. https://doi.org/10.1007/s10725-010-9445-1

Albuquerque, M. B., Santos, R. C., Lima, L. M., Melo-Filho, P. A, Nogueira, R. J. M. C., Câmara, C. A. G., \& Ramos, A. R. (2010). Allelopathy, an alternative tool to improve cropping systems. A review. Agronomy for Sustainable Development, 31, 379-395. https://doi.org/10.1051/agro/2010031

Almeida, G. D., Zucoloto, M., Zetun, M. C., Coelho, I., \& Sobreir, F. M. (2008). Estresse oxidativo em Células vegetais mediante aleloquímicos. Revista Facultad Nacional de Agronomía Medellín, 61, 4237-4247. https://doi 10.15446/rfnam

Arambewela, L. S. R., Arawwawala, L. D. A. M., \& Ratnasooriya, W. D. (2005). Antidiabetic activities of aqueous and ethanolic extracts of Piper betle leaves in rats. Journal of Ethnopharmacology, 102, 239-245. https://doi.org/10.1016/j.jep.2005.06.016 
Aumonde, T. Z., Martinazzo, E. G., Borella, J., Pedó, T., Amarante, L., Villela, F. A., \& Moraes, D. M. (2012). Alterações fisiológicas em sementes e metabolismo antioxidativo de plântulas de alface expostas à ação do extrato das folhas de Zantedeschia aethiopica Spreng. Interciencia, 37, 845-851. http://www.redalyc.org/articulo.oa?id=33925550008

Ayeni, M. J., \& Kayode, J. (2014). Laboratory studies on the effects of aqueous extracts from Sorghum bicolor stem and Zeamays (roots and tassel) on the germination and seedling growth of okra (Abelmoschus esculentus L.). Advances agriculture, 2014, 1-6. https://doi.org/10.1155/2014/958503

Bachheti, A., Sharma, A., Bachheti, R. K., Husen, A., \& Pandey, D. P. (2020) Plant Allelochemicals and Their Various Applications. In J. M. Mérillon, \& K. Ramawat (Eds.). Co-Evolution of Secondary Metabolites. Reference Series in Phytochemistry. Springer, Cham. https://doi.org/10.1007/978-3-319-96397-6_14

Bais, H. P., Vepachedu, R., Gilroy, S., Callaway, R. M., \& Vivanco, J. M. (2003). Allelopathy and exotic plant invasion: from molecules and genes to species interactions. Science, 301, 1377-1380. https://doi10.1126/science.1083245

Baldin, E. L. L., Fanela, T. L. M., Pannuti, L. E. R., Kato, M. J., Takeara, R., \& Crotti, A. E. M. (2015). Botanical extracts alternative control for silver leaf whitefly management in tomato. Horticultura Brasileira, 33, 059-065. https://doi.org/10.1590/S0102-053620150000100010

Beers, R. F., \& Sizer, I. W. (1952). A spectrophotometric method for measuring the breakdown of hydrogen peroxide by catalase. Journal of biological Chemistry, 195, 133-140. https://www.jbc.org/content/195/1/133.long

Borella, J., Martinazzo, E. G., Aumonde, T. Z., Amarante, L., Moraes, D. M., \& Villela, F. A. (2012). Respostas na germinação e no crescimento inicial de rabanete sob ação de extrato aquoso de Piper mikanianum (Kunth) Steudel. Acta Botanica Brasilica, 26, 415-420. https://doi.org/10.1590/S0102-33062012000200017

Carvalho, M. S. S., Andrade-Vieira, L. F., dos Santos, F. E., Correa, F. F., das Cardoso, M. G., \& Vilela, L. R. (2019). Allelopathic potential and phytochemical screening of ethanolic extracts from five species of Amaranthus spp. in the plant model Lactuca sativa. Scientia horticulturae, 245, 90-98. https://doi.org/10.1016/j.scienta.2018.10.001

Caser, M., Demasi, S., Caldera, F., Dhakar, N. K., Trotta, F., \& Scariot, V. (2020). Activity of Ailanthus altissima (Mill.) Swingle Extract as a Potential Bioherbicide for Sustainable Weed Management in Horticulture. Agronomy, 10, 1-17. https://doi.org/10.3390/agronomy10070965

Chon, S. U., Kim, Y. M., \& Lee, J. C. (2003). Herbicidal potential and quantification of causative allelochemicals from several Compositae weeds. Weed research, 43, 444-450. https://doi.org/10.1046/j.0043-1737.2003.00361.x

Corpes, R. S., Moraes, L. F. M., Andrade, E. H. A., Maia, J. G., Menezes, I. C., Setzer, W. N., Ramos, A. R., Silva, J. K. R. (2019). Comparison of volatile profile and antioxidant activity 
of Piper divaricatum G. Meyer (Piperaceae) using cuttings and cell tissue. Journal of the Brazilian Chemical Society, 30(11), 1-8. https://doi10.21577/0103-5053.20190128

Czarnocka, W., \& Karpiński, S. (2018). Friend or foe? Reactive oxygen species production, scavenging and signaling in plant response to environmental stresses. Free Radical Biology and Medicine, 122, 4-20. https://doi.org/10.1016/j.freeradbiomed.2018.01.011

DA Silva, J. K. R., Andrade, E. H. A., Guimarães, E. F., \& Maia, J. G. S. (2010). Essential Oil Composition, Antioxidant Capacity and Antifungal Activity of Piper divaricatum Meyer. Natural Product Communications, 5, 477-480. https://doi.org/10.1177/1934578X1000500327

DA Silva, J. K. R., Andrade, E. H. A., Kato, M. J., Carreira, L. M. M., Guimarães, E. F., \& Maia, J. G. S. (2011). Antioxidant Capacity, Larvicidal and Antifungal Activities of Essential Oils and Extracts from Piper krukoffii. Natural Product Communications, 6, 1361-1366. https://doi.org/10.1177/1934578X1100600936

DA Silva, J. K. R., Pinto, L. C., Burbano, R. M. R., Montenegro, R. C., Guimarães, E. F., Andrade, E. H. A., \& Maia, J. G. S. (2014a). Essential oils of Amazon Piper species and their cytotoxic, antifungal, antioxidant and anti-cholinesterase activities. Industrial crops and products, 58, 55-60. https://doi.org/10.1016/j.indcrop.2014.04.006

DA Silva, J. K. R., Silva, J. R. A., Nascimento, S. B., Luz, S. F. M., Meireles, E. N., Alves, C. N., Ramos, A. R., \& Maia, J. G. S. (2014b). Antifungal activity and computational study of constituents from Piper divaricatum essential oil against Fusarium infection in black pepper. Molecules, 19, 17926-17942. https://doi.org/10.3390/molecules191117926

DA Silva, J. K., Trindade, R., Alves, N. S., Figueiredo, P. L., Maia, J. G. S., \& Setzer, W. N. (2017). Essential Oils from Neotropical Piper Species and Their Biological Activities. International Journal of Molecular Sciences, $18(12), \quad 2571$. https://doi.org/10.3390/ijms18122571

Das, K., \& Roychoudhury, A. (2014). Reactive oxygen species (ROS) and response of antioxidants as ROS-scavengers during environmental stress in plants. Frontiers environmental science, 2, 1-13. https://doi.org/10.3389/fenvs.2014.00053

Demasi, S., Caser, M., Fogliatto, S., Vidotto, F., Trotta, F., \& Scariot, V. (2019). Ailanthone inhibition data on seed germination and seedling growth of Lepidium sativum L. and Raphanus sativus L. Data Brief, 26, 1-6. https://doi.org/10.1016/j.dib.2019.104550

Dubey, R. S. (2011). Metal toxicity, oxidative stress and antioxidative defense system in plants. In S. D. Gupta (Ed.), Reactive oxygen species and antioxidants in higher plants (pp.178-203). Enfield, Science Publishers.

Duke, S. O., \& Dayan, F. E. (2013). Clues to new herbicide mechanisms of action from natural sources. In J. Beck, J. Coats, S. O. Duke, \& M. Koivunen (Eds.), Pest Management with Natural Products, 1141, 203-215. https://doi.org/10.1021/bk-2013-1141.fw001

Dyer, L. A.; Richards, J.; \& Dodson, G, D. (2004). Isolation, Synthesis, and Evolutionary Ecology of Piper Amides. In L. A. Dyer, \& A. D. N. Palmer (Eds.), Piper: a model genus for 
studies of phytochemistry, ecology, and evolution (pp. 117-139). New York, Kluwer academic/Plenum publishers.

Elstner, E. F., \& Heupel, A. (1967). Inhibition of nitrite formation from hydroxylammoniumchloride: A simple assay for superoxide dismutase. Analytical Biochemistry, 70, 616-620. https://doi.org/10.1016/0003-2697(76)90488-7

Galindo, J. C., Hernández, A., Dayan, F. E., Tellez, M. R., Macías, F. A., Paul, R. N., \& Duke, S. O. (1999). Dehydrozaluzanin C, a natural sesquiterpenolide, causes rapid plasma membrane leakage. $\quad$ Phytochemistry, $\quad$ 805-813. https://doi.org/10.1016/S0031-9422(99)00303-9

Gerwick, B. C., \& Sparks, T. C. (2014). Natural products for pest control: An analysis of their role, value and future. Pest Management Science, 70(8), 1169-1185. https://doi.org/10.1002/ps.3744

Heap, I. (2020, August). The International Herbicide-Resistant Weed Database. Online. Monday. Retrieved from Available www.weedscience.org

Hermoso, A., Jimenez, I. A., Mamani, Z. A., Bazzocchi, I. L., Pinero, J. E., Ravelo, A. G., \& ValladareS, B. (2003). Antileishmanial activities of dihydrochalcones from Piper elongatum and synthetic related compounds. Structural requirements for activity. Bioorganic \& Medicinal Chemistry, 11, 3975-3980. https://doi.org/10.1016/S0968-0896(03)00406-1

Hong, N. H., Xuan, T. D., Eiji, T., Matsuo, M., \& Yuichi, O. (2002). Evaluation of the allelopathic potential of Kava (Piper methysticum L.) for weed control in rice. Weed Biology and Management, 2, 143-147. https://doi.org/10.1046/j.1445-6664.2002.00062.x

Jabran, K. (2017). Manipulation of Allelopathic. Crops for Weed Control. Springer Briefs in Plant Science, Springer International Publishing AG, Switzerland. https://doi.org/10.1007/978-3-319-53186-1

King, S. R., \& Ambika, R. (2002). Allelopathic plants. 5. Chromolaen odorata (L.). Allelopathy Journal, 9, 35-41. http://www.allelopathyjournal.org/archives/

Klein, A. L., \& Felippe, G. M. (1991). Efeito da luz na germinação de sementes de ervas invasoras. Pesquisa Agropecuária Brasileira, 26, 955-966

Leather, G. R. (1983). Weed control using allelopathic crop plants. Journal of Chemical Ecology, 9, 983-989. https://doi.org/10.1007/BF00982205

Li, Z. H., Wang, Q., Ruan, X., Pan, C. D., Jiang, D. A. (2010). Phenolics and plant allelopathy. Molecules, 15, 8933-8952. https://doi.org/10.3390/molecules15128933

Lustosa, F. L. F., Oliveira, S. C. C., \& Romeiro, L. A. (2007). Efeito alelopático de extrato aquoso de Piper aduncum L. e Piper tectoniifolium Kunth na germinação e crescimento de Lactuca sativa L. Revista brasileira de biosciencia, 5, 849-851

Moreira, D. L., Guimarães, E. F., \& Kaplan, M. A. C. (1998). A chromene from Piper aduncum. Phytochemistry, 48, 1075-1077. https://doi.org/10.1016/S0031-9422(97)00828-5 
Nakano, Y., \& Asada, K. (1981). Hydrogen peroxide is Scavenged by ascorbate-specific peroxidase in spinach chloroplasts. Plant \& cell physiology, 22, 867-880. https://doi.org/10.1093/oxfordjournals.pcp.a076232

Omid, R., Zandvakili, A. V., Barker, M. H., Fatemeh, E., \& Wesley, R. A. (2019). Comparisons of commercial organic and chemical fertilizer solutions on growth and composition of lettuce. Journal of Plant Nutrition, 42(9), 990-1000. https://doi.org/10.1080/01904167.2019.1589505

Pinto, A. C. S., Chaves, F. C. M., Santos, P. A., Nunez, C. V., Tadei, W. P., \& Pohlit, A. M. (2010). Piper peltatum: biomass and 4-nerolidylcatechol production. Planta medica, 76, 1473-1476. https://doi.org/10.1055/s-0029-1240938

Podestá, F. E., \& Plaxton, W. C. (1994). Regulation of cytosolic carbon metabolism in germinating Ricinus communis cotyledons. Planta, 194, 381-387. https://doi.org/10.1007/BF00197539

Pukclai, P., \& Kato-Noguchi, H. (2011). Allelopathic activity of Piper sarmentosum Roxb. Asian Journal of Plant Sciences, 10, 147-152. https://doi.org/10.3923/ajps.2011.147.152

R Core Team (2020). R: A language and environment for statistical computing. R Foundation for Statistical Computing, Vienna, Austria. https://www.R-project.org/

Reddy, S. V., Srinivas, P. V., Praveen, B., Kishore, K. H., \& Rao, J. M. (2004). Antibacterial constituents from the berries of Piper nigrum. Phytomedicine, 11, 697-700. https://doi.org/10.1016/j.phymed.2003.04.004

Reigosa, M., Gomes, A. S., Ferreira, A. G., \& Borghetti, F. (2013). Allelopathic research in Brazil. Acta botanica brasilica, 27, 629-646. http://dx.doi.org/10.1590/S0102-33062013000400001

Rice E. L. (1985). Allelopathy -An Overview. In. Cooper-Driver G. A., Swain T., \& Conn E. E. (eds.) Chemically Mediated Interactions between Plants and Other Organisms. Recent Advances in Phytochemistry, 19. Springer, Boston, MA. https://doi.org/10.1007/978-1-4757-9658-2_4

Rizvi, S. J. H., \& Rizvi, V. (1992). Exploitation of allelochemicals in improving crop productivity. In S. J. Rizvi, \& V. Rizvi (Eds.), Allelopathy (pp. 443-472). Springer, Dordrecht. https://doi.org/10.1007/978-94-011-2376-1_25

Roychoudhury, A., Basu, S., \& Sengupta, D. N. (2012). Antioxidants and stress- related metabolites in the seedlings of two indica rice varieties exposed to cadmium chloride toxicity. Acta Physiologiae Plantarum, 34, 835-847. https://doi.org/10.1007/s11738-011-0881-y

RStudio Team (2020). RStudio: Integrated Development for R. RStudio, Inc. Boston, MA. http://www.rstudio.com/

Seiber, J. N., Coats, J., Duke, S. O., \& Gross, A. D. (2018). Pest management with biopesticides. Frontiers of Agricultural Science and Engineering, 5, 295-300. 
https://doi.org/10.15302/J-FASE-2018238

Sharif-Zadeh, F., \& Murdoch, A. (2000). The effects of different maturation conditions on seed dormancy and germination of Cenchrus ciliaris. Seed Science Research, 10, 447-457. https://doi.org/10.1017/S0960258500000490

Sharma, P., Jha, A. B., Dubey, R. S., \& Pessarakli, M. (2012). Reactive oxygen species, oxidative damage, and antioxidative defense mechanism in plants under stressful conditions. Journal of botany, 1-26. https://doi.org/10.1155/2012/217037

Singh, A., Singh, D., \& Singh, N. B. (2009). Allelochemical stress produced by aqueous leachate of Nicotiana plumbagini folia Viv. Plant growth regulation, 58, 163-171. https://doi.org/10.1007/s10725-009-9364-1

Sodaeizadeh, H., \& Hosseini, Z. (2012). Allelopathy an environmentally friendly method for weed control. International Conference on Applied Life Sciences, 387-392.

Tigre, R. C., Silva, N.H., Santos, M.G., Honda, N. K., Falcão, E. P. S., \& Pereira, E. C. (2012). Allelopathic and bioherbicidal potential of Cladonia verticillaris on the germination and growth of Lactuca sativa. Ecotoxicology and Environmental Safety, 84, 125-132. https://doi.org/10.1016/j.ecoenv.2012.06.026

Ünyayar, S., Keleş, Y., \& Çekiç, F. Ö. (2005). The antioxidative response of two tomato species with different drought tolerances as a result of drought and cadmium stress combinations. Plant, soil and environment, 51, 57-64. https://doi.org/10.17221/3556-PSE

Vásquez, S., \& Roxana, M. (2015). Estudio fitoquímico y cuantificación de flavonoides totales de las hojas de Piper peltatum L. y Piper aduncum L. procedentes de la región Amazonas. Scientia, 7, 135-140. https://doi.org/10.21895/incres.2015.v6n1.04

Wickham, H. (2016). ggplot2: Elegant graphics for data analysis. Springer-Verlag NewYork. https://ggplot2.tidyverse.org

Wink, M., \& Schimmer, O. (2010). Molecular modes os action of defensive secondary metabolities. In M. Wink (ed.), Functions and biotechnology of plant secondary metabolites. Annual Plant Reviews (pp. 21-161). https://doi.org/10.1002/9781444318876.ch2

\section{Copyright Disclaimer}

Copyright for this article is retained by the author(s), with first publication rights granted to the journal.

This is an open-access article distributed under the terms and conditions of the Creative Commons Attribution license (http://creativecommons.org/licenses/by/4.0/). 